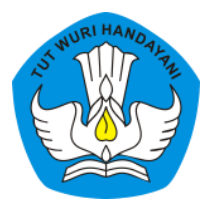

Page: 601-616

\title{
Pembelajaran Matematika Realistik Berbasis Kearifan Lokal untuk Meningkatkan Kerjasama Siswa pada Materi Segi Empat
}

\author{
Rina Asmiati \\ Sekolah Menengah Pertama Negeri 1 Muara Tiga \\ Contributor Email: mama.ayyash@gmail.com
}

Published: Juli 30, 2020

Article Url: https://ojsdikdas.kemdikbud.go.id/index.php/didaktika/article/view/149

\begin{abstract}
This research aims to apply realistic mathematics education based on local wisdom to improve collaboration and student learning outcomes in quadrilateral material in class VIID SMP Negeri 1 Muara Tiga, Pidie Regency, which consist of 28 students. This research is a classroom action research conducted using two cycles. The data collection of this research was collected at the end of every cycle by using the instrument of collaboration and student learning outcomes tests. The result of this research indicates an increase in student collaboration in each cycles. preliminary data on student collaborationis $43.75 \%$ with classical completeness $53.57 \%$ then the collaboration increased to $62.5 \%$ in the first cycle with classical mastery $67.86 \%$ and collaboration increased to $75 \%$ in the second cycle with classical mastery $85.71 \%$. So it can be concluded that realistic mathematics education based on local wisdom can increase collaboration and student learning outcomes.
\end{abstract}

Keywords: Realistics Matematic Education (RME), Local Wisdom, Collaboration. 


\begin{abstract}
Abstrak
Penelitian ini bertujuan untuk menerapkan pembelajaran matematika realistik berbasis kearifan lokal untuk meningkatkan kerja sama dan hasil belajar siswa pada materi segi empat di kelas VIID SMP Negeri 1 Muara Tiga Kabupaten Pidie yang terdiridari 28 siswa. Penelitian ini merupakan penelitian tindakan kelas yang dilakukan menggunakan dua siklus. Pengambilan data penelitian ini dilakukan setiap akhir siklus dengan menggunakkan instrumen kerjasama dan tes hasil belajar siswa. Hasil penelitian ini menunjukkan adanya peningkatan kerja sama siswa pada setiap siklusnya. Data awal kerja sama siswa 43,75\% dengan ketuntasan klasikal 53,57\% kemudian kerjasama meningkat menjadi 62,5\% pada siklus I dengan ketuntasan klasikal $67,86 \%$ dan kerja sama meningkat menjadi $75 \%$ pada siklus II dengan ketuntasan klasikal 85,71\%. Dengan demikian, dapat disimpulkan bahwa pembelajaran matematika realistik berbasis kearifan lokal dapat meningkatkan kerja sama dan hasil belajar siswa.
\end{abstract}

Kata Kunci: Pembelajaran Matematika Realistik, Kearifan Lokal, Kerja Sama.

\title{
A. Pendahuluan
}

Penerapan Kurikulum 2013 (revisi)merupakan salah satuperubahan yang dilakukan di bidangpendidikanyang diharapkan mampu untuk menegaskan keterampilan yang sesuai dengan perkembangan pendidikan era 4.0 atau sering disebut keterampilan abad 21 yang sering disingkat sebagai keterampilan 4C yaitu Communication (komunikasi), Collaboration (kolaborasi), Critical Thinking and Problem Solving (berpikir kritis dan pemecahan masalah), Creativity and Innovation (kreativitas dan inovasi)

Perkembanganera 4.0ini juga sangat berpengaruh terhadap aktivitas keseharianmanusia, sehingga sangat memungkinkan kebiasaankebiasaan lama akan ditinggalkan. Berdasarkan hal tersebut, perkembangan budaya juga akan mengalami pergeseran. Budaya yang sudah ada perlahan mulai pudar dan bahkan hilang tergantikan dengan budaya lain, misalnya saja lunturnya budaya lokal menjadi budaya yang dianggap lebih moderen dan populer. Salah satu upaya untuk melestarikan budaya yaitu dengan menjadikan budaya dan tradisi sebagai materi pembelajaran bagi siswa di sekolah sebagai salah satu 
upaya penyerapan nilai pendidikan berkaitan dengan karakter sebagai kontrol terhadap efek negatif era industri 4.0.

Aceh adalah salah satu daerah yang kaya akan budaya serta adat istiadat yang kental dengan nilai-nilai syariat islam. Akan tetapi, banyak budaya atau tradisi yang sekarang mulai pudar atau bahkan hilang. Salah satu sekolah yang terletak di provinsi Aceh adalah SMP Negeri 1 Muara Tiga yang merupakan sebuah wilayah yang terletak di pesisir Kabupaten Pidie. Pengalaman saya mengajar di sekolah ini mengajarkan saya banyak hal, antara lain adalah pudarnya tradisi-tradisi yang bisa menanamkan karakter luhur yang perlahan mulai beralih ke digital teknologi.

Salah satu karakter yang bisa ditanamkan melalui tradisi adalah semangat gotong-royong.Misalnya saja, tradisi lokal meu urup, yaitu tradisi gotong royong dalam menggarap sawah, membersihkan pekarangan dan lainnya. Perlahan tapi pasti, tradisi ini sudah sangat langka, dan lambat laun hanya akan menjadi cerita yang akan dibicarakan oleh para petani tua dan kakek nenek kita. Padahal, tradisi ini dilandasi semangat kebersamaan dan persaudaraan.

Hal tersebut terlihat sangat kentara saat pembelajaran di kelas. Siswa cenderung individualis dan malas bekerja sama. Padahal salah satu keterampilan yang diharapkan pada pembelajaran abad 21 adalah kerjasama, akan tetapi siswa SMP Negeri 1 Muara Tiga khususnya kelas VIID mengalami kesulitan dalam bekerja sama. Hal tersebut dapat dilihat dari unggulnya beberapa orang siswa sementara yang lainnya semakin tertinggal, demikian juga dengan hasil belajar, hanya beberapa orang saja yang memiliki nilai maksimal, sedangkan yang lain masih berada di batas bahkan di bawah nilai tuntas. Pada pembelajaran matematika, nilai tinggi dan maksimal hampir selalu didapatkan oleh siswa yang sama, yaitu hanya 6 orang dari 28 siswa yang selalu mendapat nilai di atas KKM dengan predikat baik dan sangat baik $(21,43 \%)$, selebihnya mendapat nilai cukup (32,14\%), (46,43\%), dan mendapat nilai di bawah KKM. 
Asumsi penulis sebagai guru, proses pembelajaran yang dilakukan masih kurang memaksimalkan kerjasama antar siswa, berdasarkan data penilaian kerjasama siswa yang hanya $43,75 \%$. Untuk meningkatkan kerjasama antar siswa, guru mencoba membiasakan pembelajaran yang bersifat individualis menjadi pembelajaran berkelompok yang berlandaskan semangat kebersamaan yaitu dengan mengadopsi tradisi meu urup yang merupakan salah satu kearifan lokal masyarakat setempat dan menerapkan pembelajaran matematika realistik (PMR) pada materi segi empat. Untuk mencapai pembelajaran yang lebih baik dari sebelumnya, PMR yang merupakan sebuah pendekatan dalam pembelajaran ini memanfaatkan lingkungan atau realitas yang dekat dengan pemahaman peserta didik agar proses pembelajaran berlangsung dengan lancar. Hal tersebut menjadikan penulis mempunyai alasan untuk melakukan penelitian menggunakan pendekatan matematika realistik dengan mengadopsi kearifan lokal meu urup dan menggunakan satuan lokal Aceh untuk meningkatkan hasil belajar melalui kerjasama kelompok di kelas VIID SMP Negeri 1 Muara Tiga Kabupaten Pidie Provinsi Aceh.

Tujuan penelitian untuk menerapkan pembelajaran matematika realistik berbasis kearifan lokal agar dapat meningkatkan kerjasama siswa pada materi segi empat di kelas VIID SMP Negeri 1 Muara Tiga. Mendeskripsikan bagaimana pembelajaran matematika realistik berbasis kearifan lokal dapat meningkatkan hasil belajar segi empat melalui kerjasama kelompok di kelas VIID SMP Negeri 1 Muara Tiga.

Pembelajaran matematika realistik berbasis kearifan lokal ini diharapkan dapat bermanfaat bagi semua pihak khususnya yang berkaitan dengan pendidikan.

Pembelajaran matematika realistik merupakan pembelajaran hasil adaptasi dari Realistic Mathematic Education (RME) yang dikembangkan di Belanda oleh Hans Frudenthal yang disesuaikan dengan situasi dan kondisi pendidikan yang ada di Indonesia. Teori RME ini mengacu pada matematika sebagai aktivitas manusia, oleh karena itu pembelajaran 
matematika harus dikaitkan dengan realita, yang berarti bahwa matematika harus berorientasi pada penerapannya dalam kehidupan harian manusia. Konsep RME ini, di Indonesia dikenal dengan Pendidikan Matematika Realistik Indonesia (PMRI) yang diprakarsai oleh Prof. Dr.R.K.Sembiring. PMRI memiliki karakteristik yang sama dengan RME (Zulkardi, 2002; Yuliana, 2017: 60-67), yaitu: penggunaan konteks, penggunaan model, penggunaan kontribusi dan kreativitas siswa, interaktivitas, dan keterkaitan dengan topik pembelajaran lain.

Berdasarkan karakteristiknya PMRI,penggunaan masalah kontekstual atau masalah sehari-hari sangat mungkin menambahkan kearifan lokal dalam setiap pembelajarannya dan dapat menanamkan karakter cinta budaya bangsa. Pada pembelajaran ini, penulis akan menerapkan kearifan lokal daerah Aceh. Kearifan lokal yang menarik bagi penulis adalah dengan mengadopsi tradisi meu urup, yaitu tradisi gotong royong dalam menggarap sawah, membersihkan pekarangan dan lainnya dengan harapan dapat meningkatkan kerjasama antar siswa. Menurut Maliati (2017:12), meu urup adalah kerja sosial yang dilakukan secara kolektif yang melibatkan setiap anggota saling terkait dan terlibat secara bersama-sama. Misalnya saja dalam mengerjakan sawah, pengerjaannya dilakukan secara bergilir dimulai dari sawah salah satu anggota kelompok melalui arahan salah satu anggota yang dituakan, kemudian anggota kelompok yang sawahnya ditanami akan ikut terlibat dalam mengerjakan sawah anggota kelompok lainnya. Praktik ini dilakukan bergilira secara berputar dalam lingkaran anggota kelompok meu urup (inner circle) hingga akhirnya semua sawah dari setiap anggota kelompok tertanami.

Pada penelitian ini, penulis mengadopsi model meu urup dalam pembelajaran dengan mengasumsikan 'sawah' sebagai 'tugas', dimana setiap siswa memiliki tugas yang harus diselesaikan dengan kelompok meu urup nya. Tugas yang diberikan akan memanfaatkan konteks yang 
dekat dengan siswa dan merupakan materi yang dipelajari di kelas VII SMP. Salah satu materi yang penulis anggap sangat dekat dengan konteks siswa yang umumnya berasal dari keluarga petani dan lingkungan sekitar sekolah maupun rumah yang dekat area persawahan adalah segi empat. Area persawahan umumnya berupa bidang datar khususnya segi empat.

Dalam mengerjakan tugas segi empat, siswa juga diminta untuk mengubah satuan baku yang diperoleh dalam satuan lokal Aceh (Seunipat) yaitu penggunaan anggota tubuh manusia itu sendiri sebagai alat ukur. Adapun beberapa anggota tubuh yang menjadi seunipatadalah sebagai berikut (Daud,2014; Rafiqa, 2018):

Siatout jaroe: seruas jari $( \pm 1 \mathrm{~cm})$

Sihah : ukuran panjang dari ujung jari tengah sampai siku / sehasta $( \pm 45 \mathrm{~cm})$ Sideupa: ukuran panjang antara ujung jari telunjuk kiri sampai ujung jari telunjuk kanan $( \pm 180 \mathrm{~cm})$

Sitapak: ukuran panjang telapak kaki dari tumit sampai ujung jari $( \pm 30 \mathrm{~cm})$

Silangkah : satu langkah $( \pm 100 \mathrm{~cm})$

Sibatee : siribee langkah 1 kilometer atau 1000 meter

Selain satuan panjang, dalam tradisi Aceh juga dikenal satuan ukuran luas. Biasanya disebutkan berdasarkan kegunaan tempat,misalnya ukuran luas sawah. Beberapa ukuran adalah sebagai berikut.

Saboh keubeung: setengah cupek $( \pm 6 \times 6$ meter $)$

Saboh cupek : setengah gupang $(12,5 \times 12,5$ meter $)$

Saboh gupang : setengahyok $(25 \times 25$ meter $)$

Siyok atau saboh umong (sepetak sawah) yang bisa ditanami dengan 16 bambu bibit padi (sinaleh) : $(50 \times 50$ meter $)$

\section{B. Metode}

Jenis penelitian ini adalah penelitian tindakan kelas (PTK) yang bertujuan memperbaiki proses pembelajaran yang terdiri dari 4 komponen, yaitu 1) perencanaan (planning), 2) tindakan (acting), 3) pengamatan (observing) dan 4) refleksi (relecting). Subjek penelitian ini 
adalah siswa kelas VIID SMP Negeri 1 Muara Tiga tahun pelajaran 20182019 yang berjumlah 28 orang. Instrumen yang digunakan dalam penelitian ini adalah lembar obsevasi kerjasama dan tes hasil belajar.

Data yang diperoleh dianalisis berdasarkan rumusan masalah masing-masing. Hasil belajar terdiri atas data hasil belajar siswa pada siklus I dan siklus II menggunakan aplikasi quizizz. Analisa data masingmasing berdasarkan ketuntasan belajar siswa secara individual mengacu pada KKM (Kriteria Ketuntasan Minimal) yang ditetapkan di sekolah yaitu 65 ,sedangkan ketuntasan klasikal terjadi apabila ada $\geq 85 \%$ siswa tuntas belajar secara individual.

Aspek kerjasama yang diamati menggunakan indikator pada tabel berikut.

Tabel.1 Instrumen Pengamatan Kerjasama Kelompok

\begin{tabular}{|l|l|l|}
\hline No & \multicolumn{1}{|c|}{ Indikator Kerjasama } & \multicolumn{1}{|c|}{ Penilaian Kerjasama } \\
\hline 1. & $\begin{array}{l}\text { Terlibat aktif dalam bekerja } \\
\text { kelompok }\end{array}$ & $\begin{array}{l}\text { Skor 1 jika 1 atau tidak ada } \\
\text { indikator yaang konsisten } \\
\text { ditunjukkan peserta didik }\end{array}$ \\
\hline 2. & $\begin{array}{l}\text { Kesediaan melakukan tugas sesuai } \\
\text { kesepakatan }\end{array}$ & $\begin{array}{l}\text { Skor 2 jika ada 2 indikator } \\
\text { konsisten ditunjukkan oleh } \\
\text { peserta didik }\end{array}$ \\
\hline 3. & $\begin{array}{l}\text { Bersedia membantu orang lain } \\
\text { dalam satu kelompok yang } \\
\text { mengalami kesulitan }\end{array}$ & $\begin{array}{l}\text { Skor 3 jika ada 3 indikator } \\
\text { konsisten ditunjukkan } \\
\text { peserta didik }\end{array}$ \\
\hline 4. & $\begin{array}{l}\text { Menghargai hasil kerja anggota } \\
\text { kelompok/tim }\end{array}$ & $\begin{array}{l}\text { Skor 4 jika 4 indikator } \\
\text { konsisten ditunjukka oleh } \\
\text { peserta didik }\end{array}$ \\
\hline
\end{tabular}

Untuk menentukan persentase (P) kerjasama kelompok dapat digunakan cara sebagai berikut.

$$
P=\frac{\text { Skor Perolehan }}{\text { Skor Maksimal }} \times 100 \%
$$

\section{Hasil dan Pembahasan}

Pembelajaran ini telah penulis terapkan pada dua kelas paralel dimana penulis diberikan tugas mengajar. Namun, hasil dari 
pembelajaran ini lebih signifikan terlihat di kelas VII D. Adapun penerapan pembelajaran pada penelitian ini, penulis lakukan menggunakan konsep Penelitian Tindakan Kelas (PTK) yang bercirikan adanya siklus. Pada setiap akhir siklus dilakukan tes untuk menguji hasil belajar siswa. Siklus akan dilakukan hingga indikator penelitian ini tercapai yaitu meningkatnya kerjasama siswa dan tercapainya ketuntasan klasikal. Berikut uraian penerapan pembelajaran yang penulis lakukan.

\section{Siklus Pertama}

\section{a. Perencanaan (Planning)}

Beberapa hal yang penulis siapkan pada tahap perencanaan ini adalah: menyusun perangkat pembelajaran (silabus, RPP, LK, bahan ajar segi empat, media pembelajaran) dan menyusun instrumen tes akhir siklus pertama menggunakan media onlinequizizzdan menyusun lembar observasi kerjasama pada materi keliling segi empat.

\section{b. Pelaksanaan (Acting)}

Pelaksanaan pembelajaran dilakukan berdasarkan perangkat pembelajaran yang sudah dibuat pada tahap perencanaan, pelaksanaan pembelajaran di kelas dapat diuraikan sebagai berikut:

\section{1) Pendahuluan}

a) Menyiapkan siswa (memberi salam, berdoa, One Day One Ayat)

b) Apersepsi: Mengingatkembalimateritentangmacam-macam bangun datar

c) Motivasi: Memotivasi peserta didikdengan cara menunjukkan secara langsung atau melalui gambar benda-bendayang berbentuk segi empat dalam kehidupan sehari-hari.

d) Menyampaikantujuanpembelajaran yang akandicapai

e) Menyampaikan langkah pembelajaran yaitu dengan membentuk kelompok meu urup dengan \pm 4 orang anggota dan setelah pembelajaran selesai akan diadakan tes individu secara online 


\section{2) Kegiatan Inti}

a) Guru menampilkan masalah kontekstual

b) Siswa di dorong untuk mengajukan pertanyaan mengenai masalah yang diberikan

c) Guru membagikan LK pada setiap siswa di kelompok

d) Siswa membaca dan memahami langkah-langkah kerja kegiatan yang ada di LK

e) Siswa diberi kesempatan untuk mengajukan pertanyaan mengenai kegiatan pada LK yang belum dipahami

f) Siswa diberikan kebebasan melakukan percobaan dan berdiskusi untuk melakukan kegiatan meu urup di LK.

g) Siswa diarahkan untuk berdiskusi/ bertukar pendapat dengan teman sekelompoknya untuk mengerjakan LK

h) Siswa diminta membaca buku referensi untuk mengaitkan penjelasan dibuku dan hasil kerja kelompoknya.

i) Guru mengawasi jalannya diskusi kelompok.

j) Siswa membuat kesimpulan mengenai rumus untuk menentukan keliling segi empat dan penggunaan lokal seunipat

k) Siswa menggunakan rumus keliling segi empat untuk menyelesaikan masalah yang diberikansecara meu urup

1) Siswa mempresentasikan hasil kerja kelompok

\section{3) Penutup}

a) Guru bersama siswa menyimpulkan rumus keliling segi empat

b) Setiap kelompok diberikan penghargaan berdasarkan keberhasilan belajar kelompoknya.

c) Guru mengajukan pertanyaan refleksi tentang pembelajaran dan meu urup, misalnya:

- Bagaimana komentarmu tentang pelajaran hari ini?

- Aktivitas mana yang sudah dan belum kuasai?

- Bagaimana saranmu tentang proses pembelajaran berikutnya?

d) Guru mengumpulkan LK siswa untuk pemberian feed back 
e) Guru menginformasikan bahwa pertemuan selanjutnya akan membahas tentang luas segi empat.
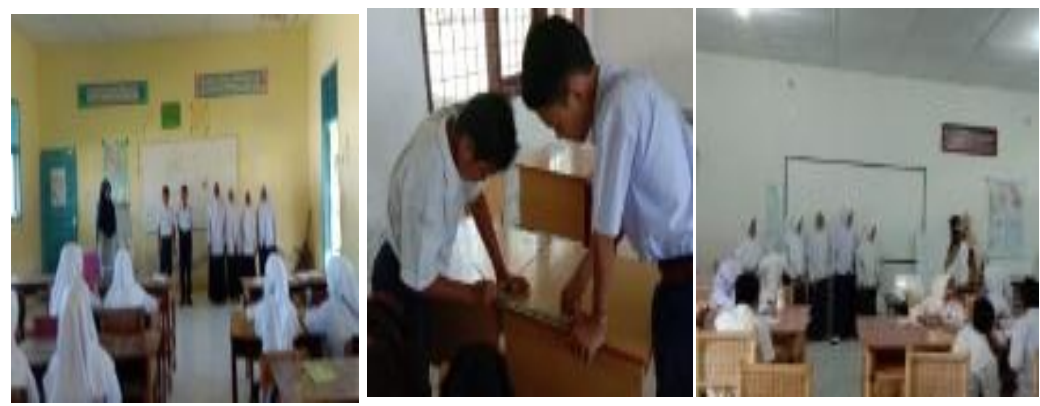

Pemilihan Kelompok, Mengerjakan Tugas, Presentasi

\section{c. Pengamatan (Observing)}

Penulis dibantu oleh seorang observer yang berasal dari teman sejawat untuk mengamati proses pembelajaran. Pengamatan dilakukan terhadap proses pembelajaran yang berlangsung dan aktifitas siswa yang berfokus pada kegiatan belajar kelompok mеи итир. Beberapa observasi dapat diuraikan sebagai berikut.

1) Pembimbingan siswa yang mengalami kesulitan masih kurang;

2) Ada siswa yang kurang memperhatikan penjelasan guru;

3) Ada siswa yang tidak mau terlibat aktif dalam kelompok;

4) Ada siswa yang keluar masuk dengan alasan ke toilet;

5) Ditemukan beberapa kesalahan dalam penghitungan keliling segi empat;

6) Ditemukan kesalahan dalam mengkonversi satuan baku dalam seunipat.

\section{d. Refleksi}

Sebagai guru, penulis menyadari bahwa pembelajaran yang dilakukan belum maksimal, hal ini terlihat cari catatan observer selama proses pembelajaran berlangsung. Sehingga guru akan memperbaiki 
proses pembelajaran dengan meningkatkan pembimbingan siswa yang mengalami kesulitan secara individu, guru akan mencoba memusatkan perhatian siswa ketika guru menjelaskan, guru juga akan mencoba menerapkan aturan-aturan yang disepakati bersama siswa sehingga tidak ada lagi siswa yang keluar masuk kelas tanpa alasan yang jelas. Guru akan mengingatkan siswa untuk mengecek kembali hasil perhitungan yang telah dilakukan dengan bantuan teman dan bimbingan guru.

\section{Siklus Kedua}

\section{a. Perencanaan (Planning)}

Siklus kedua pada tahap ini dilakukan sama seperti siklus pertama yaitu menyiapkan beberapa hal seperti pada siklus pertama dengan melakukan sedikit revisi berdasarkan refleksi hasil pembelajaran pada tahap sebelumnya. Penulis menambahkan ice breaking untuk memusatkan perhatian siswa maupun dalam melatih kerjasama kelompok, selain itu penulis juga akan memberikan pendampingan lebih intensif kepada siswa yang mengalami kesulitan, serta akan membuat aturan-aturan tertentu yang disepakati sebelumnya agar pengelolaan kelas lebih tertib.

\section{b. Pelaksanaan (Acting)}

Penulis melaksanakan kegiatan pembelajaran seperti yang telah direncanakan dengan kegiatan awal seperti pada siklus pertama dengan menambahkan ice breaking di awal pembelajaran untuk melatih kerjasama kelompok dan pada kegiatan inti untuk memusatkan perhatian siswa.

Pada kegiatan inti, siswa kembali mengerjakan LK yaitu materi luas segi empat, sedangkan guru mengintensifkan pembimbingan di kelompok dimana terdapat siswa yang mengalami kesulitan. Belajar juga dilakukan di dalam ruang kelas, siswa boleh memanfaatkan tempat yang teduh di luar ruangan untuk mengerjakan LK bersama kelompoknya. Setelah selesai bekerja di kelompok, hasilnya dipresentasikan di depan kelas, saran dan tanggapan dari kelompok lain dijadikan dasar untuk merevisi pekerjaan mereka. 
Lembar kerja dikumpulkan untuk diberikan umpan balik, kemudian diberikan tes individu yang dilakukan secara online, nilai ini akan menjadi sumbangsih untuk nilai kelompoknya. Kelompok yang mendapat nilai tertinggi dengan kerjasama terbaik akan mendapat reward dari guru. Salah satu reward yang diberikan guru berupa stiker smiley face untuk setiap anggota kelompok terbaik untuk ditempelkan di buku catatan masing-masing.
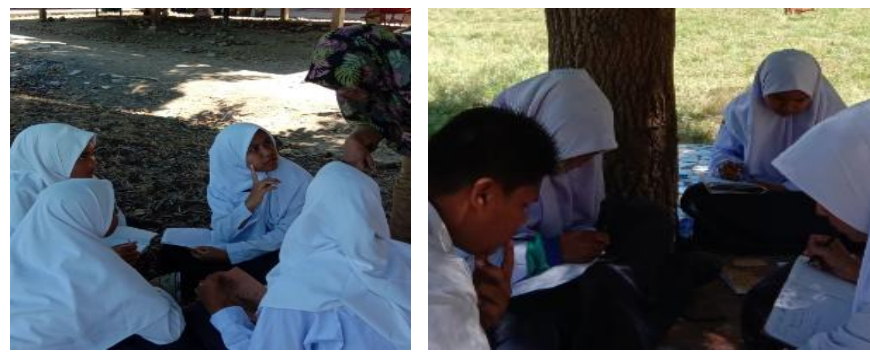

Kerja Kelompok

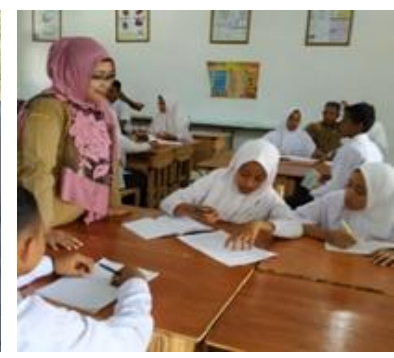

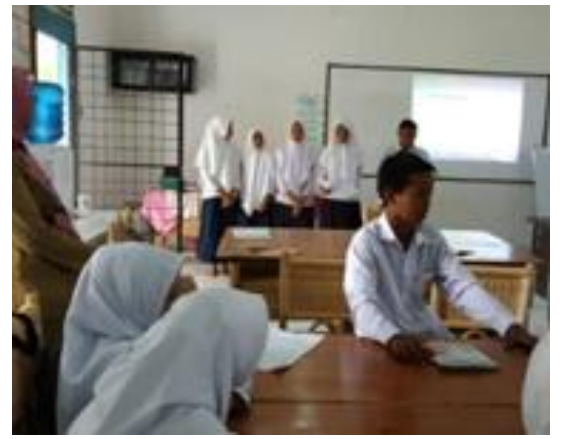

Presentasi

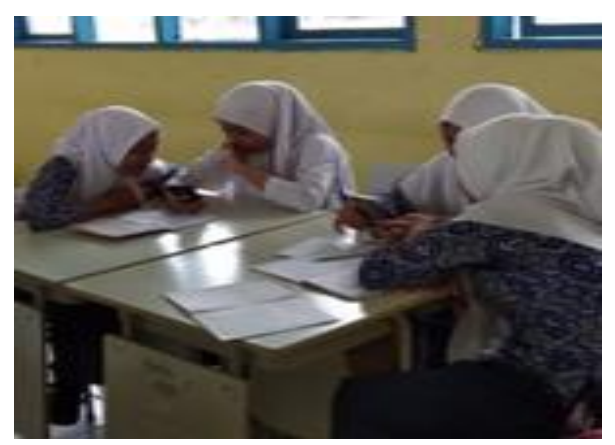

Tes Online

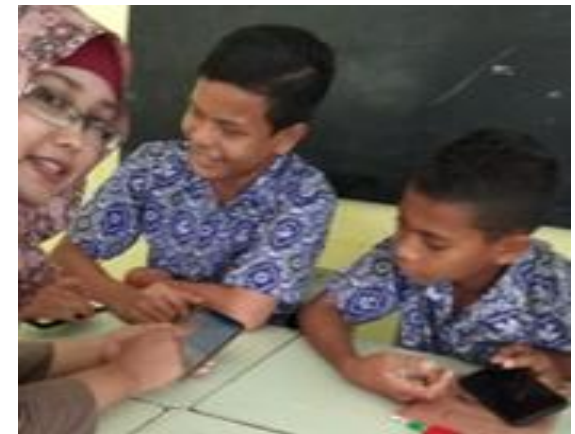

Persiapan Tes

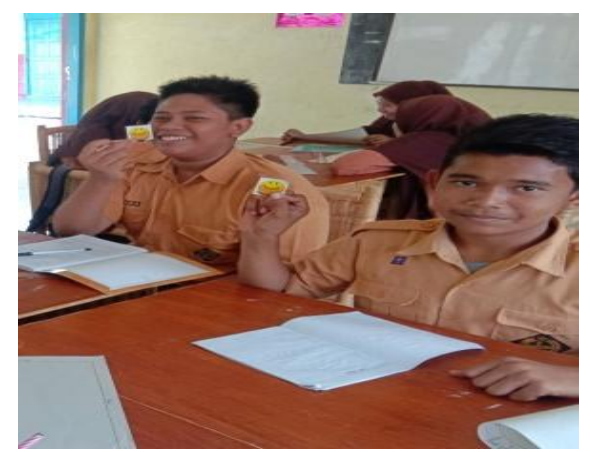

PenghargaanKelompok 


\section{c. Pengamatan (Observing)}

Berdasarkan hasil pengamatan dari observer, penampilan guru telah mengalami peningkatan pada segi menarik perhatian siswa dengan memberikan ice breaking sehingga seluruh siswa memperhatikan dengan seksama, hal ini terlihat dari antusiasme siswa ketika merespon pertanyaan yang diajukan oleh guru.

Kerjasama siswa juga mengalami peningkatan ketika bekerja di kelompok, tidak ada lagi siswa yang tidak aktif bekerja di kelompok, setiap siswa mengerjakan tugas sesuai kesepakatan dan umumnya siswa sudah bersedia membantu teman dalam satu kelompok yang sama jika mengalami kesulitan.

\section{d. Refleksi}

Berdasarkan hasil pengamatan pembelajaran dapat disimpulkan bahwa terjadi peningkatan pada tampilan guru sehingga antusiasme siswa meningkat, siswa dapat bekerjasama dengan baik serta hasil belajar juga meningkat dan ketuntasan belajar secara klasikal dapat tercapai. Sehingga penelitian ini dicukupkan sampai di siklus kedua ini

Berdasarkan data awal yaitu hanya 6 orang dari 28 orang siswa yang mendapat predikat $A$ atau B, 9 orang mendapat predikat $C$ dan 13 lainnya tidak tuntas. Dengan kata lain hanya 53,57 \% siswa yang mencapai ketuntasan dengan data kerjasama siswa hanya $43,75 \%$. Penulis menyimpulkan bahwa pembelajaran yang dilakukan belum maksimal sehingga diperlukan upaya lebih untuk memksimalkan hal tersebut khususnya dalam meningkatkan hasil belajar dan kerjasama siswa sehingga tujuan pembelajaran dapat tercapai.

Pembelajaran matematika realistik berbasis kearifan lokal ini penulis lakukan sebagai upaya melakukan perbaikan pembelajaran agar dapat membantu siswa dalam bekerja dan belajar bersama, saling berbagi dan bergotong royong dengan menggunakan konteks real yang dekat dengan lingkungan siswa.

Penerapan inovasi pembelajaran ini menghasilkan data kerjasama dan hasil belajar siswa sebagai berikut. 
Tabel 2: Perbandingan Kerjasama Kelompok SWiswa pada Siklus Pertama dan Siklus Kedua

\begin{tabular}{|l|c|c|c|}
\hline No & Kelompok & Siklus Pertama & Siklus Kedua \\
\hline 1 & 1 & $68,75 \%$ & $75 \%$ \\
\hline 2 & 2 & $75 \%$ & $81,25 \%$ \\
\hline 3 & 3 & $50 \%$ & $68,75 \%$ \\
\hline 4 & 4 & $56,25 \%$ & $62,5 \%$ \\
\hline 5 & 5 & $56,25 \%$ & $75 \%$ \\
\hline 6 & 6 & $68,75 \%$ & $87,5 \%$ \\
\hline \multicolumn{2}{|r|}{ Persentase Rata-rata } & $62,5 \%$ & $75 \%$ \\
\hline
\end{tabular}

Sementara itu, hasil belajar siswa dapat dilihat pada grafik berikut.

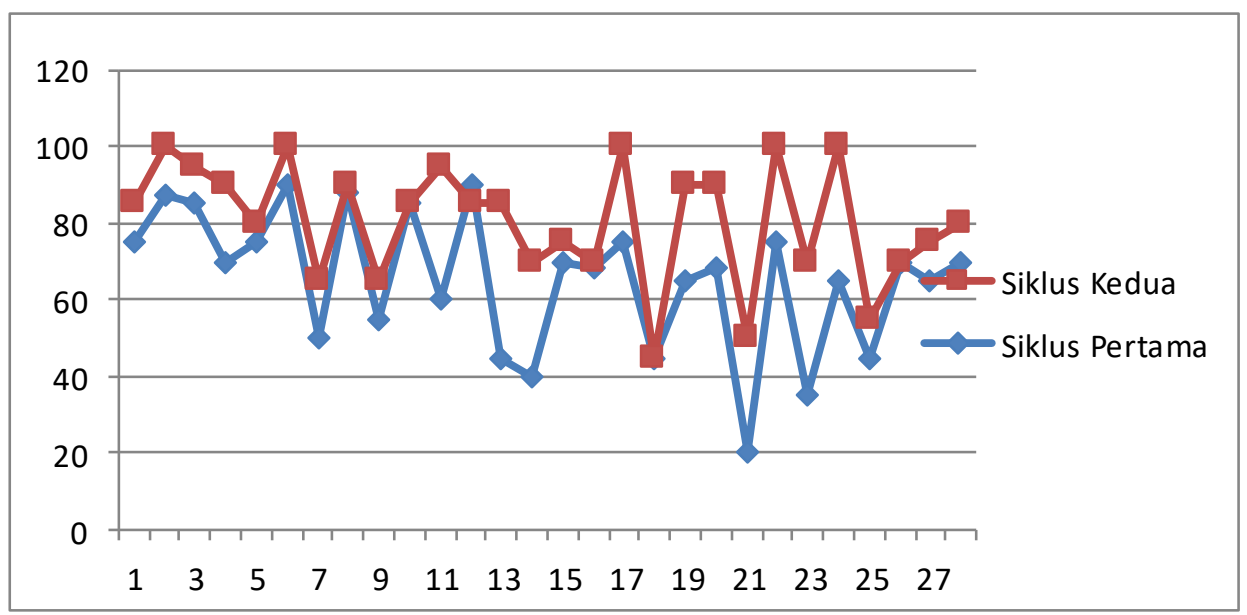

Grafik 1: Perbandingan Hasil Belajar Siklus Pertama dan Kedua

Data hasil inovasi pembelajaran dapat dirangkum pada tabel berikut.

Tabel 3:AnalisisPerbandingan Data Sebelum dan Sesudah Penelitian

\begin{tabular}{|l|c|c|c|c|}
\hline \multicolumn{1}{|c|}{ Indikator } & Data Awal & $\begin{array}{c}\text { Siklus } \\
\text { Pertama }\end{array}$ & $\begin{array}{c}\text { Siklus } \\
\text { Kedua }\end{array}$ & Keterangan \\
\hline Kerjasama Siswa & $43,75 \%$ & $62,5 \%$ & $75 \%$ & Meningkat \\
\hline Ketuntasan Klasikal & $53,57 \%$ & $67,86 \%$ & $85,71 \%$ & Meningkat \\
\hline
\end{tabular}


Seperti yang terlihat pada tabel 3 di atas bahwa pembelajaran matematika realistik berbasis kearifan lokal dapat meningkatkan kerjasama yang dapat dilihat dari tabel perbandingan data sebelum dan setelah penelitian, yang awalnya $43,75 \%$ meningkat menjadi $65,2 \%$ pada siklus pertama dan $75 \%$ pada siklus kedua. Selain itu, hasil belajar juga meningkat dari data awal 53,57 \% menjadi $67,86 \%$ pada siklus pertama dan $85,71 \%$ pada siklus kedua sehingga dapat disimpulkan ketuntasan klasikal telah tercapai, sehingga penelitian ini dihentikan.

\section{Penutup}

Pembelajaran matematika realistik berbasis kearifan lokal dapat meningkatkan kerja sama siswa dalam kelompok pada materi segi empat di kelas VIID SMP Negeri 1 Muara Tiga. Pembelajaran matematika realistik berbasis kearifan lokal dapat meningkatkan hasil belajar siswa pada materi segi empat di kelas VIID SMP Negeri 1 Muara Tiga.

\section{Ucapan Terimakasih}

Terima kasih saya sampaikan kepada Bapak Kepala Sekolah dan teman-teman guru di SMP Negeri 1, Muara Tiga, Aceh yang telah memberikan fasilitas dan bantuan sehingga penelitian tindakan kelas ini dapat diselesaikan dengan baik.

\section{Daftar Referensi}

Daud,S. (2014). Adat meugoe: Adat Bersawah. Majelis Adat Aceh.

Maliati, N. (2017). Agricultural Productivity and Farmers Welfare Involution (Case Study in Menasah Pinto Aceh Utara). Solidarity:Jurnal sosiologi Pedesaan, 5(2).

Rafiqa, A. (2018) Penggunaan Satuan Takaran Padi di Kalangan Masyarakat Indrapuri Menurut Hukum Islam. (Skripsi,Fakultas Syari'ah dan Hukum Universitas Islam Negeri Ar-Raniry, Banda Aceh).

Siahaan, A. (2017). Teachers' Reading Culture in Madrasah Tsanawiyah Environment of the Target Grant Program of School and Quality 
Component Assistance. Jurnal Ilmiah Peuradeun, 5(3), 415-430. doi:10.26811/peuradeun.v5i3.169

Siswanto, R., Sugiono, S., \& Prasojo, L. (2018). The Development of Management Model Program of Vocational School Teacher Partnership with Business World and Industry Word (DUDI). Jurnal Ilmiah Peuradeun, 6(3), 365-384. doi:10.26811/peuradeun.v6i3.322

Yuliana, R. (2017). Pengembangan Perangkat Pembelajaran Dengan Pendekatan PMRI Pada Materi Bangun Ruang Sisi Lengkung Untuk SMP Kelas IX. Jurnal Pendidikan Matematika S-1, 6(1), 6067.

Yusrizal, Y., \& Hanif, K. (2017). Increasing of Students' Motivation in Learning Physics Through the Use of Computer Simulation Media Viewed From Parents' Employment Background. Jurnal Ilmiah Peuradeun, 5(2), 201-212. doi:10.26811/peuradeun.v5i2.129

Zulkardi, Z. (2002). Developing a learning environment on realistic mathematics education for Indonesian student teachers. (Doctoral dissertation, University of Twente, Enschede). 